ISSN 1392-3196 / e-ISSN 2335-8947

Zemdirbyste-Agriculture, vol. 107, No. 2 (2020), p. 147-152

DOI 10.13080/z-a.2020.107.019

\title{
Biocontrol of strawberry pathogen Botrytis cinerea using plant extracts and essential oils
}

\author{
Lina ŠERNAITĖ, Neringa RASIUKEVIČIŪTĖ, Edita DAMBRAUSKIENĖ, \\ Pranas VIŠKELIS, Alma VALIUŠKAITĖ \\ Lithuanian Research Centre for Agriculture and Forestry, Institute of Horticulture \\ Kauno 30, Babtai, Kaunas dist., Lithuania \\ E-mail: lina.sernaite@lammc.lt
}

\begin{abstract}
Essential oils and plant extracts of the rosemary (Rosmarinus officinalis L.), bay-laurel (Laurus nobilis L.) and clove (Syzygium aromaticum L.) contain various valuable compounds that provide antimicrobial and antifungal properties. As a result, they have the potential to be used in plant-pathogen control. Botrytis cinerea is one of the main strawberry pathogens, which infects plants during various stages of growth. The study aimed to evaluate the efficacy of plant extracts and essential oils of rosemary, bay-laurel and clove, and their mixtures against $B$. cinerea in vitro. Rosemary, bay-laurel and clove extracts and essential oils were separately and in combinations mixed with potato dextrose agar media at different concentrations. Fractional inhibition concentration (FIC) indexes were calculated for the mixtures to determine synergistic, additive or antagonistic effects of the combinations of the investigated plant extracts and essential oils.

Results of the experiment showed that clove extract had the highest inhibition (100\%) of B. cinerea, and rosemary essential oil had the lowest inhibition (31.91\%). The mixtures, which managed to fully inhibit the growth of B. cinerea, were clove extract + clove essential oil, bay-laurel extract + clove essential oil and rosemary extract + clove essential oil. Synergy was found between bay-laurel extract and clove essential oil, and rosemary extract and essential oil, the FIC indexes were equal to 0.75 for both mixtures. The mixture of bay-laurel extract and bay-laurel essential oil was antagonistic as the FIC index was 2.5.
\end{abstract}

Key words: antifungal effect, biocontrol, Botrytis cinerea, essential oil, plant extract, synergy.

\section{Introduction}

Plants are a natural source of bioactive compounds, which are responsible for their antifungal, aromatic, medicinal and other properties. Some of the essential oils are well known for their antifungal properties, which are expressed through various mechanisms: disruption of cell membrane or wall, mitochondria, reduction of cell growth, inhibition of biofilm development and other. Besides, by various extraction methods, essential oils and extracts can be obtained from plants (Nazzaro et al., 2017). Plant extracts and essential oils differ in chemical composition regarding the extraction method (Danh et al., 2013). Rosemary (Rosmarinus officinalis L.), bay-laurel (Laurus nobilis L.) leaves and clove (Syzygium aromaticum L.) buds are widely used in food, medicine and cosmetic industries (Al-Kashimi, Mahmood, 2016; Oliveira et al., 2016). Antimicrobial activity and antifungal potential of rosemary essential oil have already been observed against foodborne pathogens (Fakoor, Rasooli, 2008; Soylu et al., 2010; Caputo et al., 2018). Foodborne pathogen Aspergillus niger is partly controlled by rosemary essential oil (Baghloul et al., 2017), besides it reduces A. flavus mycotoxin production (Mahmoud et al., 2014).
Derwich et al. (2009) determined the inhibitory effect of bay-laurel essential oil on human pathogenic bacteria. Clove bud essential oil consists mainly of eugenol and its derivative eugenyl acetate (Hatami et al., 2019). In a comparison of extraction methods, clove oil obtained by supercritical $\mathrm{CO}_{2}$ extraction was found to have a higher concentration of eugenol and eugenyl acetate than that obtained by steam distillation (Yazdani et al., 2005). Olea et al. (2019) determined the antifungal activity of eugenol and its derivatives against Botrytis cinerea.

Antifungal and antimicrobial activity of plant ingredients is getting increasingly more attention in plant protection (Nikkhah et al., 2017), as alternative plant protection products are needed due to high toxicity of the chemical pesticides to humans and the environment (Choudhury et al., 2018; Rosero-Hernandez et al., 2019). Biodegrable, non-toxic chemicals from plants with selective activity against pathogens could become safer disease control agents (Soylu et al., 2010).

Biopesticides derived from plants are divided into extracts and essential oils depending on the method of extraction (Lengai, Muthomi, 2018). Due to the valuable composition and properties, rosemary, bay-laurel leaves

Please use the following format when citing the article:

Šernaitė L., Rasiukevičiūtė N., Dambrauskienė E., Viškelis P., Valiuškaitė A. 2020. Biocontrol of strawberry pathogen Botrytis cinerea using plant extracts and essential oils. Zemdirbyste-Agriculture, 107 (2): 147-152. DOI 10.13080/z-a.2020.107.019 
and clove bud extracts and essential oils may be one of the options in this area. Higher efficacy of the biocontrol product could be achieved by combining several natural compounds. According to Mbunde et al. (2019), synergism occurring in herbal drugs improves efficacy, determines the faster therapeutic effect and also provides an alternative way to treat resistant microorganisms. However, a similar effect may be achieved in antifungal mixtures against plant pathogens. Several studies on the combinations of bioactive compounds can be found in the literature (Kocic-Tanackov et al., 2014; Milenkovic et al., 2018; Mbunde et al., 2019). Clove bud essential oil, together with eucalyptus essential oil, demonstrated synergistic antimicrobial activity against human pathogens Staphylococcus aureus, Escherichia coli and Microsporum gypseum (Kirui et al., 2014). AguilarGonzalez et al. (2015) investigated clove bud essential oil for antifungal effect on $B$. cinerea together with mustard essential oil on strawberries in the vapour phase.

$B$. cinerea causes grey mould, a harmful disease with a wide range of hosts (Rasiukevičiūte et al., 2018). It may infect plants at different growth stages and could result in high losses of the plants or whole yield (RoseroHernandez et al., 2019). One of the host plants is strawberry, which can get infected through various parts, like leaves, fruits, flowers, petioles and stems (Rasiukevičiūtè et al., 2018). Although $B$. cinerea is controlled using integrated disease management, the most efficient way to control this pathogen is synthetic fungicides (Abbey et al., 2019). B. cinerea, determined as a high risk pathogen, is able to develop resistance to widely used fungicides (Minova et al., 2015) as a result of new, resistant fungal strains (Yildirim, Yapici, 2007). As the negative effects of the chemical fungicides on humans and environment are already known, new ways to control pathogens are under investigation (Rasiukevičiūtè et al., 2015; 2019; Mirmajlessi et al., 2016; Valiuškaitè et al., 2017).

Based on the demand for alternatives to chemicals for controlling grey mould, which is a common strawberry disease, the aim of this study was to investigate the efficacy of essential oils and extracts of rosemary and bay-laurel leaves and clove buds against $B$. cinerea in vitro and to examine, whether the mixtures of these extracts have synergistic effect.

\section{Materials and methods}

The research was carried out in 2018-2019 at the Laboratory of Plant Protection, Institute of Horticulture, Lithuanian Research Centre for Agriculture and Forestry. Bay-laurel (Laurus nobilis L.), rosemary (Rosmarinus officinalis L.) and clove (Syzygium aromaticum L.) were selected for this research according to chemical composition of their bioactive compounds and antimicrobial and antifungal activities (Fakoor, Rasooli, 2008; Derwich et al., 2009; Soylu et al., 2010; Baghloul et al., 2017; Caputo et al., 2018; Olea et al., 2019), which have the potential to be effective against plant pathogens. Plant extracts and essential oils were produced using two methods; dried plant material was used in both of them to obtain higher yields of essential oil and to compare the efficacy of plant-based material from different extraction methods.

Isolation of plant extracts. High-pressure carbon dioxide $\left(\mathrm{CO}_{2}\right)$ extraction was used to obtain plant extracts. Dried bay-laurel and rosemary leaves and clove buds were purchased from the UAB "Sauda", Lithuania. $\mathrm{CO}_{2}$ gas, intended for the food industry ("Gaschema", Lithuania), was used in the extraction process. Twenty- five kilograms of the plant material was placed in a high-pressure $\mathrm{CO}_{2}$ extractor consisting of an extraction vessel, cooler, heater and liquid $\mathrm{CO}_{2}$ collector. Extraction parameters were selected based on pressure-temperature diagram of $\mathrm{CO}_{2}$, lower than critical point (Cunha et al., 2018). Extraction parameters were: 40 bar pressure, $10^{\circ} \mathrm{C}$ temperature and 6 hour extraction time.

Essential oil extraction. Dried bay-laurel leaves and clove buds were purchased from the Cash and Carry Ltd., Lithuania. One kilogram of the plant material was extracted using a Clevenger distillation system (Glassco, India). The time of the essential oil distillation was 2 hours (AOAC, 1990). Rosemary essential oil was obtained after transferring plant extract from $\mathrm{CO}_{2}$ extraction to the Clevenger system and collecting essential oil.

Efficacy of individual plant extracts and essential oils. Rosemary, bay-laurel and clove extracts and essential oils were separately poured into the potato dextrose agar (PDA) at these concentrations: 0, 200, $400,600,800,1000,1200,1400,1600,1800$ and 2000 $\mu \mathrm{L}^{-1}$. Discs (6 mm diameter) of 7-day old strawberry pathogen Botrytis cinerea single-spore isolate (from Laboratory of Plant Protection, Institute of Horticulture, Lithuanian Research Centre for Agriculture and Forestry isolate collection) were cut and placed on each Petri dish with the PDA and the tested products. The fungus was used from the margin of the plate and put the mycelial side down in the centre of the Petri dish amended with PDA. Isolates were incubated for 7 days at $22 \pm 2{ }^{\circ} \mathrm{C}$ temperature in the dark. The radial growth $(\mathrm{cm})$ of the $B$. cinerea colony (including the diameter of the disc) was measured after 2, 4 and 7 days. The efficacy of individual plant extracts and essential oils in vitro was expressed as mycelial growth inhibition (Cherkupally et al., 2017):

$$
\text { Mycelial growth inhibition }(\%)=\frac{\mathrm{C}-\mathrm{T}}{\mathrm{C}} \times 100 \text {, }
$$

where $\mathrm{C}$ is radial growth of the pathogen colony in the control $(\mathrm{cm}), \mathrm{T}$ - radial growth of the pathogen colony in the treatment $(\mathrm{cm})$.

The lowest concentrations of each investigated plant extract or essential oil with no visible growth of the pathogen (mycelial growth inhibition equal to 100\%) were considered to be minimal inhibition concentrations (MIC).

Efficacy of the mixtures. After evaluation of the efficacy of extracts and oils, MIC of the investigated plant extracts $(\mathrm{PE})$ and essential oils (EO) were determined: clove $\mathrm{EO} \mathrm{MIC}=1200 \mu \mathrm{l} \mathrm{L} \mathrm{L}^{-1}$, clove $\mathrm{PE} \mathrm{MIC}=600 \mu \mathrm{l}$ $\mathrm{L}^{-1}$, rosemary $\mathrm{EO} \mathrm{MIC}=2000 \mu \mathrm{L} \mathrm{L}^{-1}$, rosemary $\mathrm{PE}$ $\mathrm{MIC}=1600 \mu \mathrm{L}^{-1}$, bay-laurel EO MIC $=2000 \mu \mathrm{L}^{-1}$ and bay-laurel PE MIC $=1200 \mu \mathrm{L}^{-1}$. The efficacy of $600 \mu \mathrm{L} \mathrm{L}^{-1}$ concentration of rosemary PE differed from other investigated concentrations and was not chosen as MIC. The prepared mixtures were binary and contained plant extract and essential oil in five different ratios of the determined $\mathrm{MIC}$ of each component: $1 / 4 \mathrm{MIC}_{\mathrm{PE}}+1 / 4$ $\mathrm{MIC}_{\mathrm{EO}}, 1 / 2 \mathrm{MIC}_{\mathrm{PE}}+1 / 2 \mathrm{MIC}_{\mathrm{EO}}, \mathrm{MIC}_{\mathrm{PE}}+\mathrm{MIC}_{\mathrm{EO}}, 1 \frac{1}{4} \mathrm{MIC}_{\mathrm{PE}}$ $+1 \frac{1}{4} \mathrm{MIC}_{\mathrm{EO}}$ and $1 \frac{1}{2} \mathrm{MIC}_{\mathrm{PE}}+1 \frac{1}{2} \mathrm{MIC}_{\mathrm{EO}}$. The calculated amounts of plant extracts and essential oils were mixed with the PDA medium and further investigation of the efficacy of the mixtures was carried out in the same way as described for individual plant extracts and essential oils.

Determination of fractional inhibition concentration (FIC) indexes. A few steps were made to investigate, whether individual plant extracts and essential oils act synergistically in the mixtures. Firstly, the minimal inhibition concentrations (MIC) of the plant extract (PE) and essential oil (EO) in the mixture were 
determined. Then, fractional inhibitory concentration index $\left(\mathrm{FIC}_{\text {index }}\right)$ was calculated using the formula, adapted by Stevic et al. (2014):

$$
\mathrm{FIC}_{\text {index }}=\frac{M I C_{E O} \text { in mixture }}{M I C_{E O}}+\frac{M I C_{P E} \text { in mixture }}{M I C_{P E}}
$$

The mixture had a synergistic effect, meaning that it had higher efficacy than individual components: when evaluated FIC $_{\text {index }}<1$ the mixture had additive effect, when the efficacy of the mixture was equal to that of its components and $1 \leq \mathrm{FIC}_{\text {index }} \leq 2$; when efficacy of the mixture was lower than that of individual components, the mixture had an antagonistic effect and $\mathrm{FIC}_{\text {index }}>2$ (Kocic-Tanackov et al., 2014).

Statistical analysis. The program SAS Enterprise Guide, version 7.1 (SAS Institute Inc., USA) was applied for the analysis of the results with the ANOVA procedure. The experiments were carried out in four replicates. Duncan's multiple range test was used to determine significant differences between treatments $(P<0.05)$. Results in the figures are represented as the mean, vertical bars indicate standard deviation. Results in the table are represented as the mean \pm standard error.

\section{Results and discussion}

Efficacy of the plant extracts and essential oils. The inhibition of mycelial growth of strawberry pathogen $B$. cinerea was determined by separately mixing plant extracts and essential oils with PDA at different concentrations. The results are presented in Figure 1. Clove extract, whose lowest concentration $(200 \mu \mathrm{L}$ 1) showed more than $80 \%$ inhibition, had the highest efficacy against the pathogen. This extract inhibited the pathogen growth $100 \%$ at $600-2000 \mu \mathrm{L}^{-1}$ concentration. However, clove essential oil had versatile inhibition at $200-1000 \mu \mathrm{L}^{-1}$ and fully $(100 \%)$ inhibited growth of B. cinerea at $1200-2000 \mu \mathrm{l} \mathrm{L} \mathrm{L}^{-1}$ concentration. The differences in the efficacy of these two plant-derived products may depend on the different extraction methods.
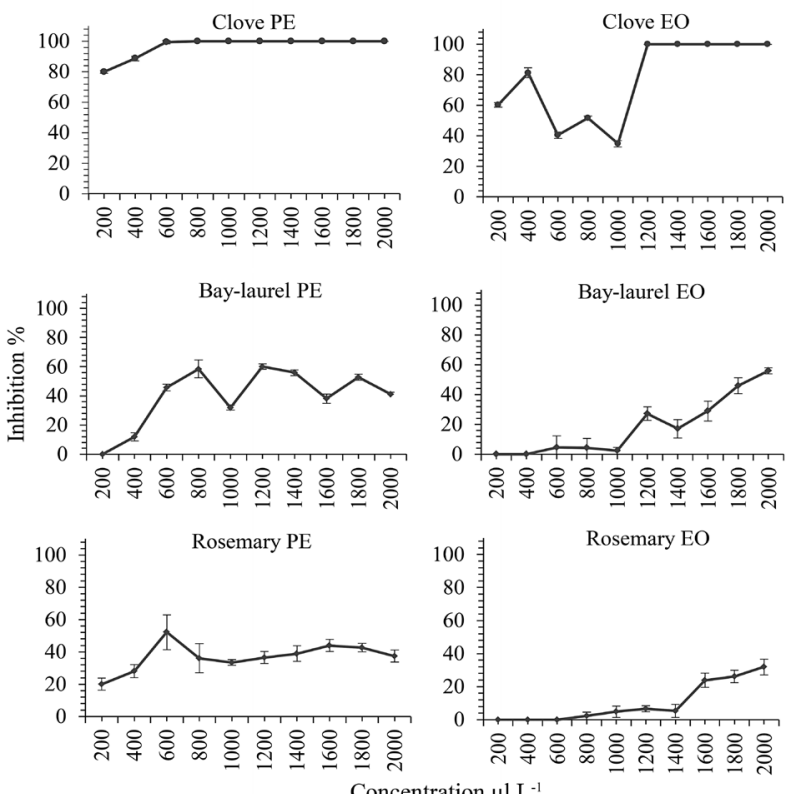

Note. Results are presented as the mean, vertical bars indicate standard deviation.

Figure 1. Inhibition (\%) of Botrytis cinerea on PDA: clove essential oil (EO) and plant extract (PE), bay-laurel $\mathrm{EO}$ and $\mathrm{PE}$ and rosemary EO and PE
Clove plant extract, as a more concentrated product of $\mathrm{CO}_{2}$ extraction, resulted in a consistent growth of the efficacy. Meanwhile, clove essential oil exhibited high efficacy at 200-1000 $\mu \mathrm{L} \mathrm{L}^{-1}$ concentration, though the composition of essential oil was not strong enough to fully suppress the pathogen growth.

Although clove products were not widely investigated on plant pathogenic fungi, there is evidence that ethanolic extract of clove $100 \%$ inhibited the growth of Sclerotium rolfsii, Alternaria alternata, Fusarium moniliformae, Rhizoctonia solani and Aspergillus niger (Singh et al., 2019). Additionally, clove essential oil was effective against phytopathogenic bacteria (Huang, Lakshman, 2010; Bozik et al., 2017).

El Alama et al. (2015) found that clove and rosemary essential oil is effective against Candida albicans. Methanol, ethanol and water extracts of rosemary demonstrated antimicrobial activity (El-Naggar et al., 2017). In our study, rosemary extract was moderately effective against $B$. cinerea with the highest inhibition of $52.21 \%$ at $600 \mu \mathrm{L} \mathrm{L}^{-1}$ and $43.97 \%$ at $1600 \mu \mathrm{L}^{-1}$. Meanwhile, rosemary essential oil was least effective of all the tested plant-derived products: it demonstrated $31.91 \%$ of inhibition at the highest $\left(2000 \mu \mathrm{L} \mathrm{L}^{-1}\right)$ concentration. It can be assumed that rosemary essential oil contained the least amount of antifungal compounds or they were not entirely extracted using hydrodistillation method, because $\mathrm{CO}_{2}$-extracted rosemary exhibited higher efficacy. Bay-laurel leaf extract did not demonstrate the high inhibition $\left(60.15 \%\right.$ at $\left.1200 \mu \mathrm{L} \mathrm{L}^{-1}\right)$. B. cinerea growth was reduced with increased concentrations of bay-laurel leaf essential oil at 1400-2000 $\mu \mathrm{L} \mathrm{L}^{-1}$, and the highest inhibition reached was $55.88 \%$. The active components of bay-laurel plant extract have also been extracted better with $\mathrm{CO}_{2}$ extraction than hydrodistillation, because higher efficacy was observed at lower concentrations compared to bay-laurel essential oil. Investigation of higher concentrations of both baylaurel plant extract and essential oil is needed, as they demonstrated potential to suppress the pathogen. Other studies determined that microemulsion with bay-laurel essential oil inhibited growth and conidia germination of A. alternata (Xu et al., 2017) and expressed bactericidal activity (Derwich et al., 2009). The determined minimal inhibition concentrations (MIC) of each tested product: clove EO MIC $=1200 \mu \mathrm{L} \mathrm{L}^{-1}$, clove PE MIC $=600 \mu \mathrm{L} \mathrm{L}^{-1}$, rosemary $\mathrm{EO} \mathrm{MIC}=2000 \mu \mathrm{L}^{-1}$, rosemary $\mathrm{PE} \mathrm{MIC} \mathrm{=}$ $1600 \mu \mathrm{L} \mathrm{L}-1$, bay-laurel EO MIC $=2000 \mu \mathrm{L} \mathrm{L}^{-1}$, bay-laurel $\mathrm{PE} \mathrm{MIC}=1200 \mu \mathrm{L} \mathrm{L}^{-1}$, were used in the further assay with mixtures.

Overall, plant extracts were more effective against $B$. cinerea compared to essential oils. It may depend on the method of the extraction of antifungal compounds.

Efficacy of the mixtures. Mixtures of two components with each tested product were formed after evaluation of individual plant extracts in vitro. The efficacy of the mixtures with the different ratios of extracts and essential oils' MIC from the previous experiment is presented in Table.

The most effective mixtures were clove bud extract and essential oil at all investigated ratios, also bay-laurel PE + clove EO and rosemary PE + clove EO, which gave $100 \%$ inhibition of pathogen growth at four mixture combinations. Clove PE + bay-laurel EO and clove PE + rosemary EO showed $100 \%$ inhibition at three tested combinations. However, other investigated mixtures increased inhibition of $B$. cinerea with higher ratio of the components in the mixture. The lowest 
Table. Mycelial growth inhibition (\%) of Botrytis cinerea by plant extracts (PE) and essential oil (EO) mixtures

\begin{tabular}{|c|c|c|c|c|c|}
\hline $\begin{array}{c}\text { Ratio of } \\
\text { MIC }_{\mathrm{PE}}+\mathrm{MIC}_{\mathrm{EO}} \\
\text { in the mixture }\end{array}$ & $\begin{array}{l}\text { clove PE + } \\
\text { clove EO }\end{array}$ & $\begin{array}{c}\text { clove PE + } \\
\text { bay-laurel EO }\end{array}$ & $\begin{array}{c}\text { clove } \mathrm{PE}+ \\
\text { rosemary EO }\end{array}$ & $\begin{array}{l}\text { bay-laurel PE + } \\
\text { clove EO }\end{array}$ & $\begin{array}{c}\text { bay-laurel PE + } \\
\text { bay-laurel EO }\end{array}$ \\
\hline $\begin{array}{c}1 / 4+1 / 4 \\
1 / 2+1 / 2 \\
1+1 \\
11 / 4+11 / 4 \\
11 / 2+11 / 2 \\
\end{array}$ & $\begin{array}{l}93.28 \pm 7.15 \mathrm{ba} \\
100.00 \pm 0.00 \mathrm{a} \\
100.00 \pm 0.00 \mathrm{a} \\
100.00 \pm 0.00 \mathrm{a} \\
100.00 \pm 0.00 \mathrm{a}\end{array}$ & $\begin{array}{c}56.62 \pm 3.67 \mathrm{k} \\
82.50 \pm 3.34 \mathrm{dfe} \\
100.00 \pm 0.00 \mathrm{a} \\
100.00 \pm 0.00 \mathrm{a} \\
100.00 \pm 0.00 \mathrm{a}\end{array}$ & $\begin{array}{l}53.53 \pm 4.16 \mathrm{lk} \\
79.41 \pm 3.81 \mathrm{gf} \\
100.00 \pm 0.00 \mathrm{a} \\
100.00 \pm 0.00 \mathrm{a} \\
100.00 \pm 0.00 \mathrm{a}\end{array}$ & $\begin{array}{l}73.97 \pm 0.74 \mathrm{ih} \\
100.00 \pm 0.00 \mathrm{a} \\
100.00 \pm 0.00 \mathrm{a} \\
100.00 \pm 0.00 \mathrm{a} \\
100.00 \pm 0.00 \mathrm{a}\end{array}$ & $\begin{array}{c}7.50 \pm 5.77 \mathrm{o} \\
43.68 \pm 2.69 \mathrm{~m} \\
72.50 \pm 8.21 \mathrm{ihj} \\
82.35 \pm 2.84 \mathrm{dfe} \\
85.15 \pm 9.95 \mathrm{dce}\end{array}$ \\
\hline $\begin{array}{c}\text { Ratio of } \\
\text { MIC }_{\mathrm{PE}}+\mathrm{MIC}_{\mathrm{EO}} \\
\text { in the mixture }\end{array}$ & $\begin{array}{c}\text { bay-laurel PE + } \\
\text { rosemary EO }\end{array}$ & $\begin{array}{c}\text { rosemary } \mathrm{PE}+ \\
\text { clove EO }\end{array}$ & $\begin{array}{l}\text { rosemary PE + } \\
\text { bay-laurel EO }\end{array}$ & $\begin{array}{c}\text { rosemary } \mathrm{PE}+ \\
\text { rosemary EO }\end{array}$ & \\
\hline $\begin{array}{c}1 / 4+1 / 4 \\
1 / 2+1 / 2 \\
1+1 \\
11 / 4+11 / 4 \\
11 / 2+11 / 2\end{array}$ & $\begin{array}{c}30.88 \pm 4.74 \mathrm{n} \\
45.15 \pm 3.48 \mathrm{~m} \\
67.06 \pm 7.22 \mathrm{j} \\
82.50 \pm 1.30 \mathrm{dfe} \\
90.44 \pm 0.56 \mathrm{bc}\end{array}$ & $\begin{array}{l}41.91 \pm 1.55 \mathrm{~m} \\
100.00 \pm 0.00 \mathrm{a} \\
100.00 \pm 0.00 \mathrm{a} \\
100.00 \pm 0.00 \mathrm{a} \\
100.00 \pm 0.00 \mathrm{a}\end{array}$ & $\begin{array}{c}42.94 \pm 2.76 \mathrm{~m} \\
50.88 \pm 2.981 \\
68.68 \pm 3.27 \mathrm{ij} \\
87.50 \pm 3.34 \mathrm{dc} \\
100.00 \pm 0.00 \mathrm{a}\end{array}$ & $\begin{array}{c}33.09 \pm 4.41 \mathrm{n} \\
54.12 \pm 4.38 \mathrm{lk} \\
67.35 \pm 7.65 \mathrm{j} \\
74.41 \pm 3.48 \mathrm{gh} \\
80.15 \pm 5.53 \mathrm{fe}\end{array}$ & \\
\hline
\end{tabular}

Note. MIC - minimal inhibition concentrations; results are presented as the mean \pm standard error; the same letter indicates no significant differences between treatments $(P<0.05)$.

efficacy $(7.50 \%)$ was shown by the mixture of $1 / 4 \mathrm{MIC}_{\mathrm{PE}}$ $+1 / 4 \mathrm{MIC}_{\mathrm{EO}}$ bay-laurel PE and EO. There are no other studies where mixtures of plant extracts and essential oils were investigated. However, studies on the combinations of essential oils can be found in the literature. The mixtures of clove and mustard (Brassica nigra) essential oils fully inhibited strawberry pathogen $B$. cinerea at various compositions (Aguilar-Gonzalez et al., 2015).

The determined fractional inhibitory indexes $\left(\mathrm{FIC}_{\text {index }}\right)$ are shown in Figure 2. Only bay-laurel PE + clove EO and rosemary PE + rosemary EO demonstrated the synergy between the components, and the inhibition was higher than that of individual components. A similar result was obtained by Aguilar-Gonzalez et al. (2015); they found a synergy between clove and mustard essential oils. Besides, clove essential oil acted synergistically with eucalyptus (Eucalyptus citriodora) essential oil against several bacteria strains (Kirui et al., 2014). A mixture of bay-laurel PE + bay-laurel EO was found to be antagonistic.
Regarding this mixture, bay-laurel EO may significantly reduce the efficacy of the bay-laurel PE, as its inhibition was higher at many concentrations according to the results in vitro (Fig. 1). Rosemary PE + clove EO and clove PE + clove EO mixtures had the same effect as their components as determined FIC index was equal to 1 and was considered as additive.

The rest of the mixtures also had additive effect as their FIC index did not exceed 1.5. The results are similar to those of Mbunde et al. (2019), who reported that most of the investigated crude plant extract mixtures had additive effect. A few synergistic interactions between crude plant extracts against human pathogenic fungi were documented by Mbunde et al. (2019). The author emphasised that despite the low efficacy as an individual component, natural components may be useful when used in mixtures because of the synergy. For example, Milenkovic et al. (2018) examined essential oils and did not find them to have antimicrobial properties

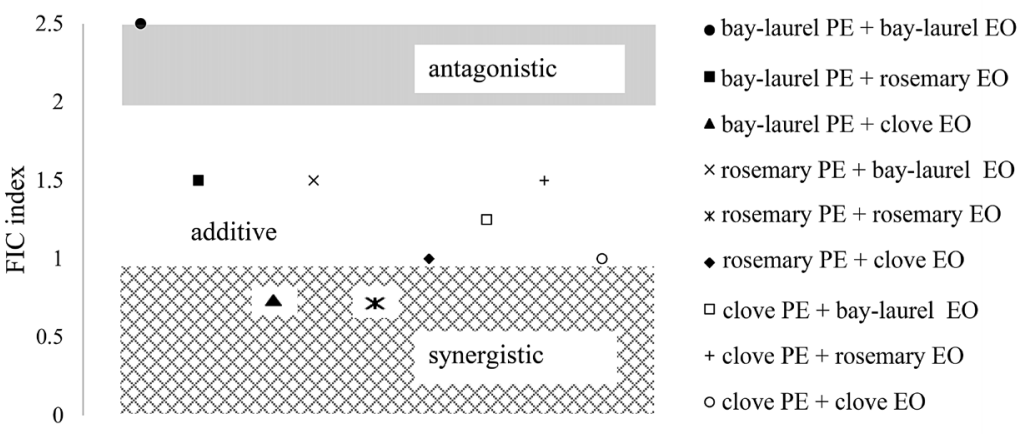

Figure 2. Fractional inhibition concentration (FIC) indexes of the plant extracts (PE) and essential oil (EO) mixtures and demonstration of the synergistic, additive and antagonistic effect

against several bacteria. However, in combination with antibiotics, the effect of mixtures varied from antagonistic to synergistic. We can partly agree with this statement, because rosemary PE + rosemary EO, not as effective as individual components, managed to have higher inhibition due to the synergy. However, further results are in contrast to those of other authors. In the case of mixture with clove PE + bay-laurel EO, again bay-laurel EO might be responsible for the lower efficacy of this extract, as clove PE was the most effective as an individual plant component. Overall, the efficacy of clove $\mathrm{EO}$ and $\mathrm{PE}$ was reduced by the second component of the mixture in many cases.

\section{Conclusions}

1. Individual plant extracts (PE) and essential oils (EO) of rosemary, bay-laurel and clove and their mixtures were investigated against strawberry pathogen Botrytis cinerea. Results revealed that the most effective was clove plant extract, and the lowest inhibition was exhibited by rosemary essential oil.

2. Binary mixtures of clove bud extract and essential oil, bay-laurel leaf extract and clove essential oil, and rosemary leaf extract and clove essential oil demonstrated the highest inhibition against $B$. cinerea and reduced the pathogen growth by up to $100 \%$. 
3. Mixtures of bay-laurel leaf extract and clove bud essential oil, and rosemary leaf extract and essential oil showed synergistic effect on the inhibition of $B$. cinerea, the fractional inhibition concentration (FIC) index was 0.75 . The mixture of bay-laurel plant extract and essential oil had an antagonistic effect $\mathrm{FIC}_{\text {index }}=2.5$.

Received 22072019

Accepted 27012020

\section{References}

1. Abbey J. A., Percival D., Abbey L., Asiedu S. K., Prithiviraj B., Schilder A. 2019. Biofungicides as alternative to synthetic fungicide control of grey mould (Botrytis cinerea) - prospects and challenges. Biocontrol Science and Technology, 29 (3): 207-228. https://doi.org/10.1080/09583157.2018.1548574

2. Aguilar-Gonzalez A. E., Palou E., Lopez-Malo A. 2015 Antifungal activity of essential oils of clove (Syzygium aromaticum) and/or mustard (Brassica nigra) in vapor phase against gray mold (Botrytis cinerea) in strawberries. Innovative Food Science and Emerging Technologies, 32: 181-185. https://doi.org/10.1016/j.ifset.2015.09.003

3. Al-Kashimi A. G., Mahmood S. A. 2016. The Nutritional value and antioxidant activity of bay-laurel leaves (Laurus nobilis L.). Basrah Journal of Veterinary Research, 15 (2): 246-259. https://doi.org/10.33762/bvetr.2016.124310

4. AOAC. 1990. Volatile oil in spices. Official methods of analysis (15 $5^{\text {th }}$ ed.) AOAC International, p. 1001.

5. Baghloul F., Mansori R., Djahoudi A. 2017. In vitro antifungal effect of Rosmarinus officinalis essential oil on Aspergillus niger. National Journal of Physiology Pharmacy and Pharmacology, 7 (3): 285-289. https://doi.org/10.5455/njppp.2017.7.7021513102016

6. Bozik M., Novy P., Kloucek P. 2017. Chemical composition and antimicrobial activity of cinnamon, thyme, oregano and clove essential oils against plant pathogenic bacteria. Acta Universitatis Agriculturae et Silviculturae Mendelianae Brunensis, 65 (4): 1129-1134. https://doi.org/10.11118/actaun201765041129

7. Caputo L., Trotta M., Romaniello A., De Feo V. 2018. Chemical composition and phytotoxic activity of Rosmarinus officinalis essential oil. Natural Product Communications, 13 (10): 1367-1370. https://doi.org/10.1177/1934578X1801301033

8. Cherkupally R., Kota R., Amballa H., Reddy B. N. 2017. In vitro antifungal potential of plant extracts against Fusarium oxysporum, Rhizoctonia solani and Macrophomina phaseolina. Annals of Plant Sciences 6 (9): 1676-1680. https://doi.org/10.21746/aps.2017.9.2

9. Choudhury D., Dobhal P., Srivastava S., Saha S., Kundu S 2018. Role of botanical plant extracts to control plant pathogens - a review. Indian Journal of Agricultural Research, 52 (4): 341-346.

10. Cunha V. M. B., Silva M. P., Costa W. A., Oliveira M. S., Bezerra F. W. F., melo A. C., Pinto R. H. H., Machado N. T., Araujo M. E., Carvalho Junior R. N. 2018. Carbon dioxide use in high-presuure extraction processes. Karame I. et al. (eds). Carbon dioxide chemistry, capture and oil recovery. IntechOpen, p. 211-240. https://doi.org/10.5772/intechopen.71151

11. Danh L. T., Han L. N., Triet N. D. A., Zhao J., Mammucari R., Foster N. 2013. Comparison of chemical composition, antioxidant and antimicrobial activity of lavender (Lavandula angustifolia L.) essential oils extracted by supercritical $\mathrm{CO}_{2}$, hexane and hydrodistillation. Food and Bioprocess Technology, 6 (12): 3481-3489. https://doi.org/10.1007/s11947-012-1026-Z

12. Derwich E., Benziane Z., Boukir A. 2009. Chemical composition and antibacterial activity of leaves essential oil of Laurus nobilis from Morocco. Australian Journal of Basic and Applied Sciences, 3 (4): 3818-3824.
13. El Alama H., El Aissami A., Ait Haj Said A., El AlaouiFaris F. E. 2015. Evaluation of anti-candida albicans activity of essential oils of six medicinal plants: Synergy concept. Journal of Chemical and Pharmaceutical Research, 7 (10): 281-284.

14. El-Naggar M. N., Abdulla G., El-Shourbagy G. A., ElBadawa A. A., El Sohaimy S. A. 2017. Antimicrobial and antioxidant activities of some plant extracts. Zagazig Journal of Agricultural Research, 44 (3): 11. https://doi.org/10.21608/zjar.2017.52305

15. Fakoor M. H., Rasooli I. 2008. Pathogen control by antioxidative characteristics of Cuminum cyminum and Rosmarinus officinalis essential oils. Acta Horticulturae, 786: $125-136$. https://doi.org/10.17660/ActaHortic.2008.786.13

16. Hatami T., Johner J. C. F., Zabot G. L., Meireles M. A. 2019. Supercritical fluid extraction assisted by cold pressing from clove buds: extraction performance, volatile oil composition, and economic evaluation. The Journal of Supercritical Fluids, 144: 39-47. https://doi.org/10.1016/j.supflu.2018.10.003

17. Huang Q., Lakshman D. K. 2010. Effect of clove oil on plant pathogenic bacteria and bacterial wilt of tomato and geranium. Journal of Plant Pathology, 92 (3): 701-707.

18. Kirui J. K., Ngure R., Bii C., Karimi P. N., Mutai C., Amugune B. K. 2014. Combined antibacterial and antifungal activities of Eucalyptus citriodora and Syzygium aromaticum essential oils. African Journal of Pharmacology and Therapeutics, 3 (1): 29-37.

19. Kocic-Tanackov S. D., Dimic G. R., Mojovic L. V., Pejin J. D., Tanackov I. J. 2014. Effect of caraway, basil, and oregano extracts and their binary mixtures on fungi in growth medium and on shredded cabbage. LWT - Food Science and Technology, 59 (1): 426-432. https://doi.org/10.1016/j.lwt.2014.05.023

20. Lengai G. M. W., Muthomi J. W. 2018. Biopesticides and their role in sustainable agricultural production. Journal of Biosciences and Medicines, 6: 7-41. https://doi.org/10.4236/jbm.2018.66002

21. Mahmoud M. A., El-Zaidy M., Al-Othman M. R., Abd El-Aziz A. R. M. Al-Gahtani M. F. 2014. Efficacy of Rosmarinus officinalis essential oil on Aspergillus flavus and parasiticus. Journal of Pure and Applied Microbiology, 8 (2): 185-190.

22. Mbunde M. V. N., Mabiki F., Innocent E., Anderccon P. 2019. Antifungal activity of single and combined extracts of medicinal plants from Southern Highlands of Tanzania. Journal of Pharmacognosy and Phytochemistry, 8 (1): 181-187.

23. Milenkovic M., Stosovic J., Slavkovska V. 2018. Synergy between essential oils of Calamintha species (Lamiaceae) and antibiotics. Natural Product Communications, 13 (3): 371-374. https://doi.org/10.1177/1934578X1801300325

24. Minova S., Seskena R., Voitkane S., Metla Z., Daugavietis M., Jankevica L. 2015. Impact of pine (Pinus sylvestris L.) and spruce (Picea abies (L.) Karst.) bark extracts on important strawberry pathogens. Proceedings of the Latvian Academy of Sciences, 69, Section B, p. 62-37. https://doi.org/10.1515/prolas-2015-0008

25. Mirmajlessi S. M., Mand M., Najdabbasi N., Larena I., Loit E. 2016. Screening of native Trichoderma harzianum isolates for their ability to control Verticillium wilt of strawberry. Zemdirbyste-Agriculture, 103 (4): 397-404. https://doi.org/10.13080/z-a.2016.103.051

26. Nazzaro F., Fratianni F., Coppola R., De Feo V. 2017. Essential oils and antifungal activity. Pharmaceuticals, 10 (4): 86. https://doi.org/10.3390/ph10040086

27. Nikkhah M., Hashemi M., Najafi M. B. H., Farhoosh R. 2017. Synergistic effects of some essential oils against fungal spoilage on pear fruit. International Journal of Food Microbiology, 257: 285-294. https://doi.org/10.1016/j.ijfoodmicro.2017.06.021

28. Olea A. F., Bravo A., Martinez R., Thomas M., Sedan C., Espinoza L., Zambrano E., Carvajal D., Silva-Moreno E., Carrasco H. 2019. Antifungal activity of eugenol derivatives against Botrytis cinerea. Molecules, 24 (7): 1239. https://doi.org/10.3390/molecules24071239 
29. Oliveira M. S., Costa W. A., Pereira D. S., Botelho J. R. S., Alencar Menezes T. O., Aguiar Andrade E. H., Silva S. H. M., Silva Sousa Filho A. P., Carvalho R. N. 2016. Chemical composition and phytotoxic activity of clove (Syzygium aromaticum) essential oil obtained with supercritical $\mathrm{CO}_{2}$. The Journal of Supercritical Fluids, 118: 185-193. https://doi.org/10.1016/j.supflu.2016.08.010

30. Rasiukevičiūtė N., Valiuškaitė A., Uselis N., Buskienė L., Viškelis J., Lukšienė Ž. 2015. New non-chemical postharvest technologies reducing berry contamination. Zemdirbyste-Agriculture, 102 (4): 411-416. https://doi.org/10.13080/z-a.2015.102.052

31. Rasiukevičiūtè N., Rugienius R., Šikšnianienė J. B. 2018. Genetic diversity of Botrytis cinerea from strawberry in Lithuania. Zemdirbyste-Agriculture, 105 (3): 265-270. https://doi.org/10.13080/z-a.2018.105.034

32. Rasiukevičiūtè N., Uselis N., Valiuškaitè A. 2019. The use of forecasting model iMETOS $®$ for strawberry grey mould management. Zemdirbyste-Agriculture, 106 (2): 143-150. https://doi.org/10.13080/z-a.2019.106.019

33. Rosero-Hernandez E. D., Moraga J., Collado I. G., Echeverri F. 2019. Natural compounds that modulate the development of the fungus Botrytis cinerea and protect Solanum lycopersicum. Plants, 8 (5): 111. https://doi.org/10.3390/plants8050111

34. Singh J., Bhatnagar S. K., Tomar A. 2019. Study of fungicidal effect of plant extracts on plant pathogenic fungi and the economy of extract preparation and efficacy in comparison to synthetic/chemical fungicides. Journal of Applied and Natural Science, 11 (2): 333-337.

https://doi.org/10.31018/jans.v11i2.2053
35. Soylu E. M., Kurt S., Soylu S. 2010. In vitro and in vivo antifungal activities of the essential oils of various plants against tomato grey mould disease agent Botrytis cinerea. International Journal of Food Microbiology, 143: 183-189. https://doi.org/10.1016/j.ijfoodmicro.2010.08.015

36. Stevic T., Beric T., Šavikin K., Sokovic M., Godevac D., Dimkic I., Stankovic S. 2014. Antifungal activity of selected essential oils against fungi isolated from medicinal plant. Industrial Crops and Products, 55: 116-122. https://doi.org/10.1016/j.indcrop.2014.02.011

37. Valiuškaite A., Uselis N., Kviklys D., Lanauskas J., Rasiukevičiūtè N. 2017. The effect of sustainable plant protection and apple tree management on fruit quality and yield. Zemdirbyste-Agriculture, 104 (4): 353-358. https://doi.org/10.13080/z-a.2017.104.045

38. Xu S., Ni Z., Ma L., Zheng X. 2017. Control of Alternaria rot of cherry tomatoes by food-grade Laurus nobilis essential oil microemulsion. Journal of Food Safety, 37 (1): e12286. https://doi.org/10.1111/jfs.12286

39. Yazdani F., Mafi M., Farhadi F., Tabar-Heidar K., Aghapoor K., Mohsenzadeh F., Darabi H. R. 2005. Supercritical CO extraction of essential oil from clove bud: effect of operation conditions on the selective isolation of eugenol and eugenyl acetate. Zeitschrift fur Naturforschung B, 60 (11): 1197-1201. https://doi.org/10.1515/znb-2005-1113

40. Yildirim I., Yapici B. M. 2007. Inhibition of conidia germination and mycelial growth of Botrytis cinerea by some alternative chemicals. Pakistan Journal of Biological Sciences, 10 (8): 1294-1300. https://doi.org/10.3923/pjbs.2007.1294.1300

ISSN 1392-3196 / e-ISSN 2335-8947

Zemdirbyste-Agriculture, vol. 107, No. 2 (2020), p. 147-152

DOI $10.13080 /$ z-a.2020.107.019

\title{
Braškių patogeno Botrytis cinerea biokontrolė naudojant augalinius ekstraktus ir eterinius aliejus
}

\author{
L. Šernaitè, N. Rasiukevičiūtè, E. Dambrauskienè, P. Viškelis, A. Valiuškaitė \\ Lietuvos agrarinių ir miškų mokslų centro Sodininkystès ir daržininkystès institutas
}

\section{Santrauka}

Rozmarinu, lauramedžių ir gvazdikmedžiu eteriniai aliejai bei ekstraktai turi vertingu junginių, suteikiančiu jiems antimikrobinių ir antigrybinių savybių, taigi šios priemonès turi potencialą būti panaudotos augalų patogenų kontrolei. Botrytis cinerea yra vienas pagrindinių braškių patogenų, augalus pažeidžiantis ịvairiais augimo tarpsniais. Tyrimo metu siekta ịvertinti kvapiojo rozmarino (Rosmarinus officinalis L.), kilniojo lauramedžio (Laurus nobilis L.) ir kvapniojo gvazdikmedžio (Syzygium aromaticum L.) ekstraktų bei eterinių aliejų efektyvumą braškiu patogeno $B$. cinerea kontrolei in vitro. Rozmarinu, lauramedžiu ir gvazdikmedžiu ekstraktai bei eteriniai aliejai buvo tirti vienkomponenčiai ir mišiniuose, skirtingomis koncentracijomis sumaišyti su bulvių dekstrozės agaro terpe. Siekiant nustatyti tirtų ekstraktų ir eterinių aliejų sinerginị, papildantị arba antagonistinị poveikị, apskaičiuoti mišinių patogeno frakcinès slopinimo koncentracijos indeksai.

Tyrimo rezultatai parodè, kad braškių patogeną $B$. cinerea kaip vienkomponentè medžiaga labiausiai (100 \%) slopino gvazdikmedžių ekstraktas, mažiausiai $(31,91 \%)$ - rozmarinų eterinis aliejus. Mišiniai, visiškai nuslopinę patogeno augimą, buvo gvazdikmedžių ekstraktas + gvazdikmedžių eterinis aliejus, lauramedžių ekstraktas + gvazdikmedžių eterinis aliejus ir rozmarinų ekstraktas + gvazdikmedžių eterinis aliejus. Sinergija buvo nustatyta tarp lauramedžių ekstrakto bei gvazdikmedžių eterinio aliejaus ir rozmarinų ekstrakto bei eterinio aliejaus; abiem atvejais patogeno slopinimo frakcinès koncentracijos indeksas buvo 0,75. Lauramedžių ekstrakto ir eterinio aliejaus mišinys buvo antagonistinis, o patogeno frakcinès slopinimo koncentracijos indekso reikšmè - 2,5.

Reikšminiai žodžiai: antigrybinis poveikis, augalinis ekstraktas, biologinè kontrolè, Botrytis cinerea, eterinis aliejus, sinergija. 